\title{
PENINGKATAN KETERAMPILAN MENULIS TEKS CERAMAH MELALUI MODEL PEMBELAJARAN CONCEPT SENTENCE
}

\author{
Willyana ${ }^{1}$, Shinta Mustika Sari TS ${ }^{2}$ \\ 1STKIP Subang, ${ }^{2}$ SMK Parahyangan \\ 1willyanaramlan25@gmail.com, 2shintamustika97@gmail.com
}

\begin{abstract}
There were several reasons for conducting this study, students' seriousness in attending writing speech text were still low and not excited. Therefore, the teacher must choose and apply an effective teaching learning model to improve students' abilities in writing speech text. This study aims to improve students' abilities in writing speech text through concept sentence model and investigated students' responses through teaching writing speech text by using concept sentence model. The quasi experiment is the research method of this study. The control and experiment class were given pre-test and post-test to know the students' abilities before and after treatment. The questionnaire also used to gain the data about students' responses through teaching writing speech text by using concept sentence model. The research finding shows that the model concept sentence is effective to improve students' ability in writing speech text. The indicators of the success of by using SPSS 23.0 are that: (1) the mean of pre-test result in the experiment class was 64,18 and post-test result in the experiment class was 81,28 , meanwhile the mean of pre-test result in the control class was 60,57 and post-test result in the control class was 71,50; (2) the students' responses through questionnaires found that the application concept sentence model was very positive.
\end{abstract}

Key words : Concept Sentence, Speech Text, Writing,

\section{ABSTRAK}

Terdapat beberapa alasan yang melatarbelakangi penelitian ini, keseriusan siswa dalam mengikuti pembelajaran menulis teks ceramah masih rendah, siswa tidak antusias pada saat pembelajaran menulis teks ceramah, kurangnya kebiasaan menulis. Oleh karena itu guru dapat memilih dan menerapkan suatu model pembelajaran yang lebih efektif untuk meningkatkan keterampilan siswa dalam menulis teks ceramah. Penelitian ini bertujuan meningkatkan keterampilan menulis teks ceramah melalui model pembelajaran Concept Sentence dan untuk mengetahui respon siswa terhadap pembelajaran menulis teks ceramah dengan menggunakan model pembelajaran Concept Sentence. Metode penelitian ini adalah quasi eksperiment, yang menggunakan kelas kontrol dan kelas eksperiment, kedua kelas diberikan pretes untuk mengetahui keadaan awal dari masing-masing kelas, setelah itu diberikan postes untuk mengetahui keadaan akhir masing-masing kelas. Dan angket untuk mengetahui respons siswa terhadap pembelajaran menulis teks ceramah dengan menggunakan model pembelajaran Concept Sentence. Berdasarkan hasil perhitungan rata-rata menggunakan SPSS 23.0. Nilai rata-rata pretes pada kelas eksperiment yaitu 
64,18 dan postes yaitu 81,28 . Sedangkan nilai rata-rata pretes pada kelas kontrol 60,57 dan postes 71,50 . Dengan demikian terdapat perbedaan hasil belajar yang signifikan antara siswa kelas kontrol dan kelas eksperiment. Respon siswa sangat posiitif terhadap penggunaan model pembelajaran concept sentence.

Kata kunci: Concept Sentence, Menulis, Teks Ceramah

\section{A. Pendahuluan}

Bahasa memiliki peranan penting di negara Indonesia, karena bahasa dianggap sebagai alat komunikasi dalam mengungkapkan pikiran dan perasaan manusia. Pernyataan tersebut memperlihatkan pentingnya bahasa dalam kehidupan manusia. Oleh karena itu, manusia harus mempelajari dan memahami bahasa. Menyadari pentingnya peranan bahasa Indonesia, maka pemerintah telah menetapkan bahasa Indonesia sebagai mata pelajaran wajib yang diajarkan di seluruh tingkat sekolah dengan tujuan agar bahasa Indonesia dapat digunakan dan dikuasai dengan baik dan benar dalam berbagai kegiatan komunikasi. Keterampilan berbahasa mempunyai empat komponen, yaitu: keterampilan menyimak (listening skills), keterampilan berbicara (speaking skills), keterampilan membaca (reading skills), keterampilan menulis (writing skills) (Tarigan, $1981: 1$ ). Namun, selama ini siswa masih menganggap pembelajaran menulis merupakan suatu pembelajaran yang membosankan dan sulit dilakukan. Rasa membosankan dan kesulitan yang muncul dari diri siswa tidak hanya disebabkan oleh siswa itu sendiri, tetapi disebabkan oleh guru yang belum berhasil membuat siswa tertarik terhadap pembelajaran bahasa Indonesia terutama pembelajaran menulis.

Pada kurikulum 2013 kelas XI pelajaran bahasa Indonesia, terdapat berbagai macam teks dan kompetensi yang harus dimiliki siswa. Salah satu kompetensi yang harus dimiliki siswa adalah kompetensi menulis teks ceramah. Siswa harus menguasai kompetensi ini, namun pada kenyataan keterampilan menulis teks ceramah pada siswa masih rendah, hal ini disebabkan: 1) keseriusan siswa dalam mengikuti pembelajaran menulis teks ceramah masih rendah, 2) siswa tidak berantusias pada saat pembelajaran menulis teks ceramah, 3) kurangnya kebiasaan menulis. Kurangnya kebiasaan menulis pada siswa 
membuat mereka sulit menuangkan ide-idenya dalam bentuk tulisan. Menyikapi permasalahan tersebut, dibutuhkan suatu strategi pembelajaran yang tepat dalam menulis teks ceramah. Selama ini metode pembelajaran yang digunakan oleh guru masih bersifat informatif. Guru menjadi satu-satunya sumber informasi dan berperan aktif dalam kegiatan pembelajaran, sehingga seringkali siswa terbiasa menerima pengetahuan dari guru. Dengan permasalahan tersebut, peneliti mencoba menerapkan ide baru untuk meningkatkan kemampuan menulis teks ceramah, yaitu dengan menggunakan model pembelajaran Concept Sentence. Model yang digunakan dalam penelitian ini diharapkan mampu mengoptimalkan hasil belajar mengajar.

Menulis ialah menurunkan atau melukiskan lambang-lambang grafik yang menggambarkan suatu bahasa yang dipahami oleh seseorang, sehingga orang-orang lain dapat membaca lambang-lambang grafik tersebut kalau mereka memahami bahasa dan gambaran grafik itu (Tarigan, 2013 : 22). Selain itu, Morsey (1976) (Tarigan, $2013: 4)$ juga berpendapat bahwa menulis dipergunakan untuk melaporkan/memberitahukan, serta memengaruhi maksud dan tujuan seperti itu hanya dapat dicapai dengan baik oleh orang-orang yang dapat menyusun pikirannya dan mengutarakannya dengan jelas, kejelasan ini bergantung pada pikiran, organisasi, pemakaian katakata, dan struktur kalimat.

Ceramah adalah pembicaraan di depan umum yang berisi penyampaian suatu informasi, pengetahuan, dan sebagainya. Yang menyampaikan adalah orang-orang yang menguasai di bidangnya dan yang mendengarkan biasanya melibatkan banyak orang (Priyanto, 2013 : 29). Pendapat serupa juga dikemukakan oleh Kosasih (2017 : 75) menyatakan bahwa ceramah adalah jenis komunikasi di depan umum yang berisi penyampaian suatu informasi, dan sebagainya. Penyampaiannya adalah orang-orang yang menguasai bidang tertentu dan pendengarnya bisa melibatkan banyak orang.

Concept sentence merupakan salah satu teknik dari cooperative learning, dimana siswa belajar dengan kelompoknya untuk membuat 
beberapa kalimat sesuai dengan kata kunci yang telah diberikan oleh guru kepada siswa. Pembentukan kelompok didasarkan pada kartu kata yang dimiliki oleh setiap siswa, dan setiap siswa membentuk satu kalimat yang telah dipelajari sebelumnya. concept sentence ini dibuat seperti game sehingga siswa bersemangat untuk memenangkan game ini. Setiap kelompok akan membahas pola kalimat yang telah diberikan oleh guru, setelah diberikan batas waktu tertentu, maka setiap kelompok harus mengirim wakil dari masing-masing kelompok sebanyak dua orang kedepan. Wakil dari kelompok diharuskan memecahkan beberapa kata kunci dari yang telah diberikan. (Shoimin, 2014 : 37) Model pembelajaran concept sentence merupakan model pembelajaran yang diawali dengan menyampaikan kompetensi, sajian materi, membentuk kelompok heterogen, guru menyiapkan kata kunci sesuai materi bahan ajar, dan tiap kelompok membuat kalimat berdasarkan kata kunci. Berdasarkan pandangan para ahli di atas dapat disimpulkan bahwa model concept sentence ialah model pembelajaran yang diawali dengan cara memberikan kartu-kartu yang berisi kata kunci kepada siswa untuk dibuat menjadi beberapa kalimat, yang selanjutnya disusun menjadi sebuah paragraf. Model ini akan membantu siswa dalam membuat sebuah teks yaitu dengan cara mengembangkan kata kunci yang telah diberikan oleh guru, sehingga siswa menjadi lebih bersemangat dalam belajar karena model ini akan dibuat seperti sebuah permainan. Dari permasalahan-permasalahan diatas maka perlu suatu pembelajaran yang dapat meningkatkan keterampilan menulis teks ceramah melalui model Concept Sentence dan untuk mengetahui respon siswa terhadap pembelajaran menulis teks ceramah dengan menggunakan model Concept Sentence.

\section{B. Metode Penelitian}

Dalam penelitian ini, metode yang digunakan adalah metode eksperimentt. Metode ini digunakan untuk mengetahui akibat perlakuan model Concept Sentence terhadap pembalajarn menulis teks ceramah. Desain dalam penelitian ini adalah kelompok kontrol nonekivalen yaitu bagian dari bentuk quasi eksperiment. Pada quasi 
Didaktik : Jurnal IImiah PGSD STKIP Subang, ISSN Cetak : 2477-5673 ISSN Online : 2614-722X Volume V Nomor 2, Desember 2019

eksperiment, subjek tidak dikelompokan secara acak, tetapi peneliti mengambil subjek apa adanya, Russfendi (1998). Hal ini dilakukan dengan pertimbangan bahwa, kelas yang ada telah terbentuk sebelumnya, sehingga tidak perlu lagi dilakukan pangelompokan secara acak.

Populasi yang penelitian ini adalah peserta didik kelas XI SMK PGRI Subang tahun ajaran 2019/2020. Dikarenakan, penelitian ini adalah penelitian quasi eksperiment maka peneliti mempertimbangkan kemam-puan awal kelas kontrol dan kelas eksperiment. Penentuan kelas kontrol dan kelas eksperiment di ambil berdasarkan catatan yang dimiliki guru sehingga diperoleh dua kelas, yaitu kelas kontrol yaitu kelas yang memiliki nilai tertinggi, sedangkan kelas eksperiment adalah kelas yang memiliki nilai terendah. Berdasarkan penentuan tersebut maka peneliti memilih kelas XI TKJ (Teknik Komputer Jaringan) 1 sebagai kelas eksperiment dan XI TKJ (Teknik Komputer Jaringan) 2 sebagai kelas kontrol.
Pengumpulan data dalam penelitian ini, menggunakan teknik tes dan non tes. Teknik tes digunakan untuk mengetahui peningkatan keterampilan menulis teks ceramah melalui model concept sentence, sedangkan teknik non tes adalah angket yang digunakan mengetahui respon siswa terhadap penggunaan model concept sentence pada pembelajaran keterampilan menulis teks ceramah. Pertanyaan penelitian dianalisis menggunakan statistika deskriptif dengan teknik presentase; sedangkan hipotesis penelitian dijawab menggunakan uji $\mathrm{n}$ beda rata-rata (t-test) dan dibantu dengan program perangkat lunak (software) SPSS 23.0.

\section{Hasil Penelitiian dan Pembahasan}

Data yang diperoleh kemudian dianalisis, dalam penelitian ini hasil dari pretes, postes kemampuan menulis teks ceramah dan angket respon siswa terhadap penggunaan model concept sentence.

1. Hasil Pretes kemampuan menulis teks ceramah siswa kelas eksperimentt dan kelas control

Hasil perhitungan data tes awal peserta didik kelas eksperimentt 
memperoleh nilai terendah 54 dan nilai tertinggi 75 , dengan nilai ratarata 64,18 dan standar deviasinya 5,586. Sedangkan hasil perhitungan data tes awal peserta didik kelas kontrol memperoleh nilai terendah 45 dan nilai tertinggi 75 , dengan nilai rata-rata 60,57 dan standar deviasinya 7,026.

2. Hasil Postes kemampuan menulis teks ceramah siswa kelas eksperimentt dan kelas control

Hasil perhitungan data tes akhir peserta didik kelas eksperimentt memperoleh nilai terendah 65 dan nilai tertinggi 89 , dengan nilai ratarata 81,28 dan standar deviasinya 6,048 . Sedangkan hasil perhitungan data tes akhir peserta didik kelas kontrol memperoleh nilai terendah 62 dan nilai tertinggi 80 , dengan nilai rata-rata 71,50 dan standar deviasinya 5,474.

Pengujian prasyarat analisis dilakukan sebelum melakukan analisis data. Prasyarat yang digunakan dalam penelitian ini adalah uji normalitas dan uji homogenitas. Pengolahan data dilakukan dengan bantuan SPSS 23.0. Uji normalitas pada penelitian ini digunakan untuk mengetahui distribusi data pada hasil pembelajaran menulis teks ceramah siswa baik sebelum diberi perlakuan atau setelah diberi perlakuan, apakah data berdistribusi normal atau tidak. Uji normalitas menggunakan rumus Kolmogorov-Sminov dalam perhitungan menggunakan program SPSS 23.0. Untuk mengetahui normal atau tidak nya adalah jiga Sig>0,05 maka normal dan jika Sig<0,05 maka dapat dikatakan tidak normal. Berdasarkan perhitungan dengan menggunakan SPSS 23.0, sebaran data dapat dikatakan normal, karena (signifikasi) Sig. lebih besar dari 0,05 dengan nilai pada kelas eksperimentt memiliki Sig. 0,200 pada tes awal dan tes akhir. Sedangkan kelas kontrol juga memiliki Sig. 0,200 pada tes awal dan tes akhir.

Tahap selanjutnya adalah uji homogenitas, digunakan untuk mengetahui apakah nilai tes kelas eksperiment dan kelas kontrol mempunyai varian yang sama atau tidak. Hasil signifikasi (sig) uji homogenitas tes awal (pretest) memiliki nilai Sig. 0,338 dan uji homogenitas tes akhir (posttest) memiliki nilai Sig. 0,844. Karena nilai Sig $>0,05$ maka dapat dinyatakan bahwa pembelajaran menulis teks ceramah dengan menggunakan 
model concept sentence memiliki data yang homogen, sehingga data tersebut telah memenuhi syarat untuk dianalisis Angka Levene Statistic.

Pengujian hipotesis dilakukan untuk menjawab rumusan masalah yang diajukan yaitu dengan menggunakan uji Paired Sample TTest. Uji $\mathrm{t}$ pretest dan posttest bertujuan untuk mengetahui ada tidaknya peningkatan keterampilan menulis teks ceramah melalui model pembelajaran concept sentence. Simpulan penelitian dinyatakan signifikan apabila nilai probalitas $<0,05$. Hipotesis dari penelitian ini adalah, Ho: Tidak ada peningkatan keterampilan menulis teks ceramah dengan menggunakan model pembelajaran concept sentence. Ha: Terdapat peningkatan keterampilan menulis teks ceramah dengan menggunakan model pembelajaran concept sentence. Berdasarkan perbandingan nilai probabilitas (sig.). Jika nilai probalitas Sig. >0,05 maka Ho diterima dan Ha ditolak. Jika nilai probalitas Sig. <0,05 maka Ho ditolak dan Ha diterima. Berdasarkan hasil perhitungan maka, Ho ditolak dan $\mathrm{Ha}$ diterima. Oleh karena itu, terdapat peningkatan keterampilan menulis teks ceramah dengan menggunakan model pembelajaran

concept sentence.

3. Hasil angket respon siswa terhadap pembelajaran menulis teks ceramah dengan menggunakan model concept sentence.

Berdasarkan hasil angket yang digunakan untuk mengetahui respon siswa terhadap pembelajaran menulis teks ceramah dengan menggunakan model Concept Sentence, maka dapat diperoleh hasil, siswa lebih menyukai pembelajaran menulis teks ceramah dengan menggunakan model concept sentence dibandingkan sebelumnya, dengan alasan menulis teks ceramah lebih mudah dikerjakan dengan menggunakan model pembelajaran concept sentence. Kemudian, Siswa lebih antusias dalam mengerjakan teks ceramah bersama dengan kelompoknya karena model ini dibuat seperti permainan, sehingga siswa tidak merasa bosan pada saat pembelajaran berlangsung. Selanjutnya, siswa yang pasif juga menjadi lebih aktif dalam proses pembelajaran, begitupula siswa lain yang lebih paham dapat membantu siswa yang kurang paham sehingga 
terjalinnya kerjasama ketika pembelajaran berlangsung.

\section{Kesimpulan}

Kesimpulan hasil penelitian ini dipaparkan sebagai berikut. Pertama, siswa yang mendapatkan pembelajaran menulis dengan menggunakan model pembelajaran concept sentence, keterampilan menulis teks ceramah siswa lebih meningkat dibandingkan dengan yang tidak menggunakan model concept sentence. Kedua, respon siswa dalam penggunaan model concept sentence adalah lebih menyukai, lebih antusias, lebih paham dan siswa juga lebih aktif pada pembelajaran menulis teks ceramah setelah menggunakan model concept sentence, jika dibandingkan dengan pembelajaran biasa.

\section{DAFTAR PUSTAKA}

Kosasih, Engkos. (2017). Cerdas Berbahasa Indonesia. Jakarta: Erlangga

Priyanto, Dwi. (2013). Modul Pengayaan Bahasa Indonesia untuk SMAMA kelas XI. Surakarta: Putra Nugraha

Ruseffendi, E.T. (1998). Statistik Dasar Untuk Penelitian Pendidikan. Bandung: IKIP Bandung Press.
Shoimin, Aris. (2018). 68 Model Pembelajaran Inovatif dalam Kurikulum 2013. Yogyakarta: Ar-Ruzz Media

Tarigan, Henry Guntur. (1981). Menulis sebagai suatu keterampilan berbahasa. Bandung: Angkasa

Tarigan, Henry Guntur. (2013). Menulis Sebagai Suatu Keterampilan Berbahasa. Bandung: Angkasa. 